\title{
MЕХАНІЗМ ФОРМУВАННЯ КОНКУРЕНТОСПРОМОЖНОСТІ ПІДПРИЄМСТВ В СУЧАСНИХ ЕКОНОМІЧНИХ УМОВАХ
}

\section{MECHANISM OF FORMATION OF COMPETITIVENESS OF ENTERPRISES IN MODERN ECONOMIC CONDITIONS}

\author{
Гріщенко Ірина Василівна \\ викладач, \\ Вінницький навчально-науковий інститут економіки \\ Західноукраїнського національного університету \\ ORCID: https://orcid.org/0000-0002-4429-4579 \\ Білецька Наталія Вікторівна \\ кандидат економічних наук, \\ Вінницький кооперативний інститут \\ ORCID: https://orcid.org/0000-0001-6922-3614 \\ Одінцова Ольга Олександрівна \\ старший викладач, \\ Донецький національний університет імені Василя Стуса \\ ORCID: https://orcid.org/0000-0001-5644-3394 \\ Grischenko Irene \\ Vinnytsia Educative and Research Institute \\ of West Ukrainian National University \\ Biletska Natalia \\ Vinnytsia Cooperative Institute \\ Odintsova Olga \\ Vasyl' Stus Donetsk National University
}

В статті зазначено, що формування конкурентоспроможності підприємств може розглядатися з різних позицій: на основі ресурсної теорії; у рамках концепції ціннісно-орієнтованого управління; на базі концепції розвитку інституційного середовища; з точки зору кластерного підходу. Виділено ряд властивостей інституційного середовища, які безпосередньо впливають на конкурентоспроможності підприємств: рівень розвитку цільового ринку, визначальний рівень конкуренції підприємств, які випускають і продають аналогічні види продукції; ступінь компетентності державних інститутів, які застосовують різні інструменти регулювання поведінки підприємств, у тому числі щодо надання різноманітних преференцій, починаючи від розміщення держзамовлень та податкових пільг та закінчуючи прямими бюджетними дотаціями; ссрормованість інноваційного середовища, що сприяє розробці нових перспективних технологій та високотехнологічних видів продукції, особливо у пріоритетних галузях. Запропоновано двосторонній механізм кластерних об'єднань підприємств.

Ключові слова: конкуренція, конкурентоспроможність, фрактори, середовище.

В статье отмечено, что фрормирование конкурентоспособности предприятий может рассматриваться с разных позиций: на основе ресурсной теории; в рамках концепции ценностно-ориентированного управления; на основе концепции развития институциональной среды; с точки зрения кластерного подхода. Выделен ряд свойств институциональной среды, непосредственно влияющих на конкурентоспособности предприятий: уровень развития целевого рынка, определяющий уровень конкуренции предприятий, которые выпускают и продают аналогичные виды продукции; степень компетентности государственных институтов, применяющих разные инструменты регулирования поведения предприятий, в том числе по предоставлению разнообразных преференций, начиная от размещения госзаказов и налоговых льгот и заканчивая прямыми бюджетными дотациями; сформированность инновационной 
среды, способствующая разработке новых перспективных технологий и высокотехнологичных видов продукции, особенно в приоритетных отраслях. Предложен двусторонний механизм кластерных объединений предприятий.

Ключевые слова: конкуренция, конкурентоспособность, фракторы, среда.

The article refers to the fact that the level of enterprise costs was actually identified with the level of competitiveness, so increasing the competitiveness of the enterprise stands the reducing of all types of costs. The possibility of distinctioness of manufactured products continues to be an important direction in the development of enterprise competitiveness. Local companies should focus their efforts on the production of new products, which may differ in configuration, packaging, level of service, focusing on different reference groups of consumers. Sources of competitive advantage should be realized through the formation of competitive strategies of enterprises. It was noted that in the environment of substantial change of conditions of conducting economic activity, formation of competitiveness of the enterprises can be considered from the various positions: on the basis of the resource theory; within the concept of value-oriented management; based on the concept of the institutional environment development; in terms of a cluster approach. A number of properties of the institutional environment that directly affect the competitiveness of enterprises were identified: the level of development of the target market, the determining level of the competition of enterprises that produce and sell similar products; the degree of the competence of state authorities that use various tools to regulate the behavior of enterprises, including the provision of various preferences, starting from the setting of government orders and tax benefits and ending with the direct budget subsidies; the formation of an innovative environment that promotes the development of new promising technologies and high-tech products, especially in priority areas; introduction of a system of socio-cultural factors that will form a certain (effective or ineffective) type of behavior of enterprises - participants in the market competition. A two-way mechanism of cluster associations of enterprises was proposed.

Keywords: competition, competitiveness, factors, environment.

Постановка проблеми. В умовах зниження темпів економічного зростання і карантинних обмежень, пов'язаних 3 військовими діями та Сході та пандемією COVID-19, які суттєво плинули на вітчизняну економіку, проблема підвищення конкурентоспроможності підприємств набуває першочергового значення. Необхідно також врахувати, що починаючи 3 90-х років минулого століття були зруйновані існуючі фрінансово-господарські зв'язки підприємств, які фрункціонували на той період, нові ще не були сорормовані, а керівництво з боку держави було мінімальним. Фінансові кризи 2007-2009 рр. та 2014-2016 рр., зменшення обсягів діяльності у зв'язку з пандемією починаючи 32020 р., спровокували перехід вітчизняних підприємств на сировинну модель економічного розвитку, що у свою чергу привело до збільшення експортної складової на товарних ринках, і вплинуло на спад економіки. Однак, економічна політика, яка передбачає компенсацію зменшення активності ринків за рахунок зростання сировинної складової в структурі економіки при створенні регулюючих державних інститутів, на сучасному етапі не відповідає вимогам економічної системи. В зв'язку з чим, у якості державних пріоритетів 3'явилися нові вектори: науково-технічний розвиток, інновації та модернізація підприємств, відповідно до яких застосовуються нові механізми та інструменти регулювання економічних відносин, здійснюється державна підтримка підприємств.
Останнім часом пріоритетним являється новий погляд на формування економічної політики, усвідомлюється необхідність створення нових інститутів і будування господарських взаємозв'язків за принципово новою основою. Було прийнято Проект «Стратегії сталого розвитку України до 2030 року» № 9015/2018, Указ президента України «Про Цілі сталого розвитку України на період до 2030 року» № 722/2019, регіональні стратегії розвитку на період до 2027 року. Однак, ті заходи що застосовуються сьогодні в рамках програми розвитку економіки, особливо у сорері механізмів управління конкурентоспроможністю підприємств, спрямовані на вирішення окремих локальних проблем і являються недостатньо ефективними, а стан підприємств суттєво не покращується.

Аналіз останніх досліджень і публікацій. Теорія конкуренції і конкурентних переваг ґрунтується на класичних працях Д. Рикардо, А.О. Курно, А. Маршала, Дж. Робінсона, П. Самуельсона, С. Фішера, Р. Шмалензі. Найбільш вагомий внесок у розвиток теоретичної концепції фрормування конкурентоспроможністю підприємств вніс М.В. Портер, який звернув увагу на важливу роль у розвитку конкуренції нових форм територіальної організації економічної діяльності - кластерів. Накопичений досвід управління конкурентним потенціалом підприємств доводить ефективність застосування кластерних підходів, що відображені у роботах Р. Барнета, 3. Бек- 
кера, Т. Візлера, 3. Гошала, Р. Менша, Р. Мінцберга, Э. Менссрілда, Б. Санто, Б. Твісса, С. Фельдмана, Й. Шумпетера, В.П. Баранчєєва, С.Д. Бешельова, Ю.В. Вертакова, Г.Я. Гольдштейна, Л.М. Гохберга, В.А. Кабанова, Н.Ю. Круглова, Н.П. Масленникова, В.М. Мішина та ін. Разом 3 тим, незважаючи на наявність багаточисельних досліджень у сорері підвищення конкурентоспроможності підприємств і створення кластерів, в економічній літературі відсутнє комплексне представлення про використання кластерних стратегій для підвищення конкурентоспроможності галузей в цілому та їх окремих сегментів.

Виділення невирішених раніше частин загальної проблеми. Питання дослідження механізму формування конкурентоспроможності підприємств в сучасних економічних умовах 3 урахуванням чинників зовнішнього та внутрішнього впливу в наукових працях розкрито недостатньо, тому потребує подальшого дослідження.

Формулювання цілей статті (постановка завдання). Метою статті $є$ розробка комплексного підходу розробки механізму фрормування конкурентоспроможності підприємств в сучасних економічних умовах.

Виклад основного матеріалу дослідження. Конкурентоспроможність підприємств визначається сукупністю його конкурентних переваг. Однак, у більшості наукових робіт [1, с. $216-218 ; 2$, с. $87 ; 3$, с. $174 ; 4$, с. 223] фрормування конкурентних переваг підприємств традиційно розглядається з очки зору зовнішньоекономічної діяльності (абсолютних переваг підприємства у відповідній галузі, загальних переваг, співвідношення факторів виробництва, глобальної стратегічної конкуренції).

Так, наприклад, в наукових працях [5, с. 208; 6, с. $31 ; 7]$ міститься твердження, що чим нижчий рівень витрат на підприємствах, тим більший рівень їх конкурентоспроможності. Основна увага концентрується на рівні витрат, які здійснюються підприємствами при виробництві різних видів продукції, або сорерах надання послуг. Таким чином, рівень витрат підприємств фрактично ототожнюється 3 рівнем конкурентоспроможності, внаслідок чого підвищення конкурентоспроможності підприємства напряму залежить від зменшенні всіх видів витрат. В наукових працях $[1$, с. 220 ; 2, с. $88 ; 3$, с. 175; 4, с. 224], де відображені дослідженням підвищення конкурентоспроможності в реальному секторі економіки, джерела конкурентних переваг підприємств визначаються або рівнем витрат, або ступенем дисреренціації продукції. Безумовно, нижчий рівень витрат відображає можливості підприємств розробляти, випускати і продавати вироблену продукцію за ціною нижчою, ніж аналогічні товари у конкурентів. Що особливо актуально в умовах зниження темпів економічного зростання, та зменшення платоспроможності споживачів, оскільки зменшення цін являється вагомою конкурентною перевагою для споживачів та покупців. Особливо це стосується при виробництві та реалізації продукції масового попиту. При орієнтації підприємств на дешеві або недорогі ринкові сегменти, можливість застосування цінової конкуренції може стати вагомою конкурентною перевагою, але стратегічний підхід підвищення конкурентоспроможності вимагає пошуку нових джерел конкурентних переваг [2, с. $87 ; 5$, с. $208 ; 6$, с. $31 ; 7]$.

Також слід враховувати, що одним 3 важливих напрямів розвитку конкурентоспроможності підприємств залишається диференціація продукції, для чого вітчизняним підприємствам необхідно сконцентрувати свої зусилля та ресурси на випуску нових різновидів продукції, яка може відрізнятися за комплектацією, упаковкою, рівнем сервісного обслуговування, 3 відповідним орієнтуванням на різні рефрерентні групи споживачів. Оскільки, при фрормуванні та реалізації стратегії підвищення конкурентоспроможності доцільно застосовувати стратегію розвитку продуктової політики та збільшення асортименту.

Отже, наведені джерела конкурентних переваг необхідно реалізовувати шляхом формування конкурентних стратегій на підприємствах. Для реалізації даного завдання перш за все необхідно застосовувати нематеріальні активи (корисні моделі, бренди, об'єкти промислової власності), які можуть бути вагомим джерелом конкурентних переваг.

В умовах кардинальної зміни умов ведення економічної діяльності на підприємствах, фрормування їх конкурентоспроможності може розглядатися з наступних позицій:

- на основі ресурсної теорії;

- у рамках концепції ціннісно-орієнтованого управління;

- на базі концепції розвитку інституційного середовища;

- 3 точки зору кластерного підходу [1, с. 217; 4, c. 224; 7].

Ресурсна теорія ґрунтується на твердженні щодо унікальності кожного економічного суб'єкта. Відповідно до даної теорії фрорму- 
вання конкурентних переваг здійснюється за допомогою диференціації підприємства від безпосередніх конкурентів, які випускають та реалізовують аналогічні види продукції. Отже, у межах ресурсної теорії механізм фрормування стійких конкурентних переваг підприємств полягає в удосконаленні їх економічного поведінки на ринку, тобто фрормуванні унікальних (які не піддаються копіюванню конкурентами) ключових компетенцій. Також, положення ресурсної теорії та (складеної відповідно до неї) концепції динамічного розвитку стають підґрунтям для срормування механізму стійких конкурентних переваг підприємств у виявленні нових видів ресурсів, наявність та застосування яких безпосередньо впливає на цінність та унікальність продукції для споживачів. Отже, джерелом конкурентних переваг підприємств стає його здатність до формування певних компетенцій і ресурсів, наявність яких здатна вплинути на поведінку споживачів, реалізації продукції на ринку, в умовах нестабільності [1, с. 217].

Концепція ціннісно-орієнтованого управління ґрунтується на стратегічному підході до підвищення конкурентоспроможності підприємства шляхом максимізації його вартості. Відповідно даної концепції на підприємствах запроваджується система проектного управління, оскільки вона сприяє підвищенню вартості підприємства, яке здійснює виробництво диференційованої продукції та реалізовується на різних ринках. Однак, незважаючи на те, що послідовна реалізація даних завдань може сприяти збільшенню вартості підприємства, остаточно неможливо простежити прямий зв язок між реалізацією даних заходів і підвищенням цінності продукції для споживачів [4, с. 224; 7].

На базі концепції розвитку інституційного середовища, конкурентоспроможність підприємства залежить від рівня розвитку існуючих економічних інститутів, що фрормують інституційне середовище, в якому фрункціонує дане підприємство. Крім того, інститути як фрактори взаємодії між підприємствами, зменшують ризики, які виникають внаслідок невизначеності зовнішнього економічного середовища, шляхом фрормуванням певної структури взаємозв'язків між ними, та визначають їх поведінку у процесі конкурентної боротьби [1, с. 217; 7].

Отже, ми можемо виділити ряд характерних властивостей, які безпосередньо впливають на конкурентоспроможність підприємств:

- рівень розвитку цільового ринку, рівень конкуренції між підприємствами, які випускають і реалізовують аналогічні види продукції;
- рівень компетентності державних інститутів, які запроваджують різноманітні інструменти регулювання поведінки підприємств, у тому числі щодо предоставлення різноманітних пресреренцій, починаючи від розміщення держзамовлень і застосування податкових пільг, та закінчуючи прямими бюджетними дотаціями;

- сорормованість інноваційного середовища, що сприяє розробці нових перспективних технологій та високотехнологічних видів продукції, особливо у пріоритетних галузях;

- запровадження системи соціокультурних чинників, які фрормуватимуть певний (ефективний чи неефективний) тип поведінки підприємств - учасників ринкової конкуренції.

Сорормована таким чином система взаємодії сприятиме стимулюванню підвищення конкурентоспроможності підприємств суміжних галузей, які застосовуватимуть у процесі своєї діяльності більш високоякісну продукцію, що у свою чергу являється основою для створення кластера. В результаті відбуватиметься суттєве покращення всіх економічних показників відповідно по всьому ланцюжку економічної взаємодії, починаючи від постачальників сировини, виробників, та закінчуючи продавцями продукції. Внаслідок чого, відбуватимуться позитивні зміни у якості продукції, що у свою чергу підвищить рівень задоволеності цільового ринкового сегменту. Також, покращення якісних характеристик продукції, яка виготовлятиметься в межах кластеру, вплине на економічну поведінку конкурентів, оскільки їм доводиться використовувати більш фрінансово та матеріально затратні методи конкурентної боротьби. При організації кластеру підприємствам, що спеціалізуються на виробництві продукції (призначеної для одного і того ж ринкового сегменту), і здійснюють конкурентну боротьбу, доводиться постійно адаптуватися до підвищення вимог стосовно якості продукції, а також до мінливих економічних умов, що у свою чергу може призвести до фрормування спільної економічної ідеї $[1$, с. 216-218; 3, с. $174 ; 4$, с. 223; 7].

Також, кластери стимулюватимуть запровадження інновацій у діяльність підприємств, оскільки вони зможуть більш оперативно реагувати на потреби споживачів цільових ринкових сегментів, завдяки тісним продуктивним взаємовідносинам. Загальні фактори конкурентоспроможності для підприємств, що входять до кластеру, змушуватимуть їх розвивати наявні конкурентні переваги, що відмінні від переваг інших підприємств. Що у 
свою чергу, приводитиме до появи та запровадження інновацій у їх діяльності. Кластер сприятиме орормуванню нових напрямків діяльності, оскільки буде доступна достовірна інфрормація стосовно ринкових сегментів, що залишаються незасвоєними, адже всередині кластера бар'єри входження на ринок виявляються нижчими ніж у відокремлених підприємств, що суттєво зменшує ризик при запровадженні нових видів діяльності.

Слід зазначити, що всередині кластерів існують спеціальні механізми, які сприяють еорективному взаємообміну інфрормацією та координації інтересів підприємств. До перших ми можемо віднести:

- економічні відносини, що фрормуються у рамках профресійних об'єднань;

- коопераційні та виробничі зв'язки, що історично склалися внаслідок певної територіальної близькості підприємств - учасників кластерного об'єднання;

- галузеві структури, що захищають економічні інтереси учасників кластера;

- моделі економічної поведінки підприємств, що спрямовані на продуктивну та довгострокову співпрацю.

До другої групи ми можемо включити:

- стійкі партнерські зв'язки між підприємствами, їх власниками та керівництвом;

- наявність часткової власності всередині кластерного об'єднання.

Отже, формування та розвиток конкурентоспроможності підприємств у рамках кластерних об єднань відбуватиметься за допомогою підвищення ефективності діяльності окремих підприємств, збільшення можливостей до запровадження інновацій всіх учасників кластеру, стимулювання розвитку нових економічних напрямків.

На нашу думку, застосування кластерного підходу є найбільш ефрективним у процесі під- вищення конкурентоспроможності підприємств, оскільки поєднує в собі ефрективні концепцій фрормування джерел конкурентних переваг з точки зору виявлених раніше конкурентних детермінант (детермінант конкурентних сил і детермінант конкурентної позиції) в рамках фрормування механізму конкурентних переваг. У Зв язку з цим саме запровадження кластерних стратегій являється одним 3 найбільш перспективних механізмів фрормування конкурентоспроможності підприємств в сучасних економічних умовах.

Висновки. Сучасний стан вітчизняної економіки спонукає підприємства до запровадження серйозних зусиль, які спрямовані на фрормування, підтримку та розвиток їх конкурентоспроможності. Це вимагає ретельного вивчення та ефективного застосування основних принципів, узагальнених у сучасній теорії конкурентоспроможності. Основними принципами $€$ необхідність проведення постійної модернізації всіх економічних процесів, вдосконалення методів діяльності та виробництва по всьому ланцюгу руху продукції підприємства, аналізу існуючих та виявлення найбільш перспективних фрінансових та економічних ресурсів, які можуть бути використані у процесі підвищення конкурентоспроможності підприємства, застосування системного підходу до у процесі підвищення конкурентоспроможності на всіх етапах діяльності підприємств (починаючи від планування, виробництва та закінчуючи реалізацією нових видів продукції), послідовної реалізації стратегії розвитку конкурентоспроможності на основі використання кластерного підходу. Перспективність використання кластерного підходу підвищення конкурентоспроможності підприємств обумовлена також і тим, що реалізація даного завдання відбуватиметься у взаємодії підприємств, наукових установ та організацій, органів державного управління.

\section{СПИСОК ВИКОРИСТАНИХ ДЖЕРЕЛ:}

1. Поліщук Н.В. Функціонування економічних систем: моделі складових результативності : монографрія. Вінниця : ВНАУ, 2010. 396 с.

2. Ярмоленко В.О., Поліщук Н.В. Складові результативності ффункціонування складних систем як об'єкти моделювання. Вісник Черкаського університету. Серія Економічні науки. Черкаси : ЧНУ, 2012. № 33(246). С. 86-93.

3. Ярмоленко В.О., Поліщук Н.В. Складові результативності економічного процесу: парадигма кількості та якості. Ринки товарів та послуг України в умовах економічного зростання : збірник наукових праць міжнар. наук.-практ. конф., 11 вересня 2008 р. Вінниця, 2008. С. 173-178.

4. Гріщенко І.В., Кобаль О.А. Оцінка показників в процесі фрінансового планування підприємства. Перспективи розвитку фінансово-економічного простору України : зб. наук. праць. Вінниця, 2020. С. $223-225$.

5. Гріщенко І.В. Оцінка показників фрінансової стійкості підприємства. Перспективи розвитку фрінансовоекономічного простору України : зб. наук. праць. Вінниця, 2020. С. 208-211. 
6. Гріщенко І.В., Білецька Н.В., Циганчук В.А., Мазур О.В. Методи забезпечення ефеективності інвестиційно-інноваційних проектів. Вісник Львівського торговельно-економічного університету. Львів : Видавництво Львівського торговельно-економічного університету, 2020. Вип. 60. С. 30-34.

7. Гріщенко І.В., Гринчук Т.П. Основні аспекти фінансового планування в системі фінансової безпеки підприємства. Економіка та суспільство. 2020. № 22. DOI: https://doi.org/10.32782/2524-0072/2020-22-14

\section{REFERENCES:}

1. Polischuk N.V. (2010) Funktsionuvannia ekonomichnykh system: modeli skladovykh rezultatyvnosti [Functioning of the economic systems: models of constituents of effectiveness]. Vinnytsia: VNAU. (in Ukrainian)

2. Yarmolenko V.O., Polischuk N.V. (2012) Skladovi rezultatyvnosti funktsionuvannia skladnykh system yak obiekty modeliuvannia [Constituents of effectiveness of functioning of the difficult systems as design objects]. Visnyk Cherkaskoho universytetu. Seriia - Ekonomichni nauky, no. 33(246), pp. 86-93. (in Ukrainian)

3. Yarmolenko V.O., Polischuk N.V. (2008) Skladovi rezultatyvnosti ekonomichnoho protsesu: paradyhma kilkosti ta yakosti [Constituents of effectiveness of economic process: paradigm of amount and quality. Proceedings of the Rynky tovariv ta posluh Ukrainy $v$ umovakh ekonomichnoho zrostannia (Ukraine, Vinnytsia, September 11, 2008), Vinnytsia, pp. 173-178. (in Ukrainian)

4. Hrischenko I.V., Kobal O.A. (2020) Otsinka pokaznykiv v protsesi finansovoho planuvannia pidpryiemstva [An estimation of indexes is in the process of the financial planning of enterprise]. Proceedings of the Perspektyvy rozvytku finansovo-ekonomichnoho prostoru Ukrainy (Ukraine, Vinnytsia, April 08-09, 2020), Vinnytsia: Krok, pp. 223-225. (in Ukrainian)

5. Hrischenko I.V. (2020) Otsinka pokaznykiv finansovoi stiikosti pidpryiemstva [Estimation of indexes of financial firmness of enterprise]. Proceedings of the Perspektyvy rozvytku finansovo-ekonomichnoho prostoru Ukrainy (Ukraine, Vinnytsia, April 08-09, 2020), Vinnytsia: Krok, pp. 208-211. (in Ukrainian)

6. Hrischenko I.V., Biletska N.V., Tsyhanchuk V.A., Mazur O.V. (2020) Metody zabezpechennia efektyvnosti investytsiino-innovatsiinykh proektiv [Methods of ensuring the effectiveness of investment and innovation projects]. Visnyk Lvivskoho torhovelno-ekonomichnoho universytetu, no. 60, pp. 30-34. (in Ukrainian)

7. Hrischenko I.V., Hrynchuk T.P. (2020) Osnovni aspekty finansovoho planuvannia v systemi finansovoi bezpeky pidpryiemstva [The main aspects of financial planning in the financial security of the enterprise]. Ekonomika ta suspilstvo, no. 22. DOI: https://doi.org/10.32782/2524-0072/2020-22-14 (in Ukrainian) 